[Agr. Biol. Chem., Vol. 36, No. 4, p. 596 603, 1972]

\title{
Protein Metabolism in the Fowl
}

\section{Part IV Possibility of Conversion of Tyrosine to Phenylalanine in the Adult Rooster}

\author{
By Teru IsHIBAshI \\ Department of Agricultural Chemistry, Faculty of Agriculture, \\ The University of Tokyo, Tokyo, Japan \\ Received September 17, 1971
}

\begin{abstract}
To confirm the possibility of conversion of $\mathrm{Tyr}$ to Phe as one of the reasons why the adult rooster is capable of maintaining its positive nitrogen balance on a Phe-free diet for a long period, $\mathrm{U}-14 \mathrm{C}-\mathrm{L}-\mathrm{Ty}$ and $2{ }^{14} \mathrm{C}-\mathrm{DL}-\mathrm{T} y \mathrm{r}$ were injected to the roosters and, for reference, U-14C-L-Tyr to the rats fed a Phe-free diet.

In the case of fowls, hydrolyzates of liver, blood and muscle protein contained radioactivities only in Phe and Tyr fractions.

It was confirmed that radioactivity of Phe was not due to contamination of radioactive Tyr and transmission of ${ }^{14} \mathrm{C}$ from $\mathrm{Tyr}$ to Phe was not due to transcarboxylation, because ${ }^{14} \mathrm{C}$ was found in the benzoic acid derived from Phe when U-14 $\mathrm{C}-\mathrm{Tyr}$ was injected and it was not found in $\mathrm{CO}_{2}$ derived from carboxyl group of Phe when 2-14C-Tyr was injected.

But the amount of Phe converted from Tyr was too little to meet the amount of Phe used for synthesis of body protein both in fowls and rats.
\end{abstract}

Recently attention has been directed to evaluation of amino acid requirement using plasma free amino acid level. Smith and Scott ${ }^{1,21}$ with chicks and Stockland et al. ${ }^{3 !}$ with rats have shown the phenylalanine (Phe) requirement for growth. These results agreed well with those of other investigators who used growing test, ${ }^{4,5)}$ nitrogen balance test and carcass assay test. ${ }^{6,7)}$

They all reported that Phe was essential for growth, and Leveille el al. ${ }^{81}$ and Johnson and Fisher ${ }^{9 \prime}$ also reported that Phe was essential for maintenance and production in the fowl. Chicks lost their appetite for a Phe-free diet, even though tyrosine (Tyr) was added enough, and they could not grow and maintain their body weights consequently. ${ }^{101}$

But adult roosters fed a Phe-free diet which contained Tyr, maintained their positive nitrogen balance for a long period. ${ }^{11,121}$

There may be three kinds of possibilities for the fact that fowls adapted themselves to Phe-deficiency; 1) synthesis of Phe, 2) high reutilization rate of $\mathrm{Phe}$ and 3 ) conversion from Tyr to Phe.

There are some reports concerning the conversion of $\mathrm{Tyr}$ to Phe. Aqvist ${ }^{131}$ reported that a direct conversion of Phe to Tyr was indicated by stable isotope experiments and the high ${ }^{15} \mathrm{~N} \%$ excess in Phe after feeding of ${ }^{15} \mathrm{~N}-\mathrm{T}$ yr would seem to indicate that this conversion is reversible, in contrast to the results in the feeding experiments..$^{3-5)}$

On the other hand, Udenfriend and Cooper ${ }^{14}$ reported that Tyr can be formed from Phe by enzymes and it is unlikely that this reaction is reversible and certainly the enzyme responsible for converting $\mathrm{Phe}$ to $\mathrm{Tyr}$ did not catalyze the reverse reaction.

Udenfriend and Mitoma ${ }^{151}$ also reported that with ${ }^{14} \mathrm{C}$-labeled Tyr in rats, dogs and rabbits, conversion to Phe did not take place in vivo 
to any detectable extent, contrary to the finding of Aqvist.

Moreover, Grau and Steele ${ }^{16 /}$ reported that mice fed a Phe-deficient diet converted the absorbed Phe to Tyr of liver protein and to $\mathrm{CO}_{2}$ to a lesser degree than did the animals fed the diet containing enough Phe for normal growth, and absorbed ${ }^{14} \mathrm{C}$ - $\mathrm{Ty}$ r was not converted to Phe of liver protein by either the normal or the Phe-deficient mice.

The results given by chicks on a Phe-free diet indicated that the amount of Phe-synthesized, conversion rate of Tyr to Phe and the amount of ${ }^{14} \mathrm{C}$ expired into the respiratory $\mathrm{CO}_{2}$ after injection of ${ }^{14} \mathrm{C}$-Phe were very little. ${ }^{10 \text { ? }}$

As adult roosters on a Phe-free diet, in contrast with chicks, could maintain positive nitrogen balance for a long period, they might be able to convert Tyr to Phe in the body, in order to adapt themselves to Phe-deficiency.

In this paper, the possibility of conversion of Tyr to Phe was studied with the adult roosters which were fed a Phe-free diet, injected labeled Tyr intracelially.

This possibility was also investigated with rats for reference.

\section{MATERIALS AND METHODS}

1. Conversion of Tyr to Phe in rats. To study the possibility of conversion of Tyr to Phe in rats, three male albino rats of the Wistar strain weighing 280 to $340 \mathrm{~g}$ were supplied with a Phe-free diet ad libitum for 4 days and $4.4 \mu \mathrm{Ci}$ of U-4C-L-Tyr per rat was injected at the left facies medialis intracelially.

The diet and care of rats were the same as reported in the previous report. ${ }^{12}$

The rats were killed by cutting the aorta carotis $15 \mathrm{hr}$ after injection and their livers were taken out.

2. Conversion of Tyr to Phe in adult roosters. To study the possibility of conversion of $\mathrm{T} Y \mathrm{r}$ to Phe in adult roosters, two White Leghorn roosters, at 18 months of age, were supplied with a Phe-free diet at the rate of $30 \mathrm{~g}$ per $\mathrm{kg}$ body weight per day. ${ }^{12}$

The fowl which was supplied with the Phe-free diet for 5 days and confirmed to maintain its positive nitrogen balance prior to injection was injected 42.0
"Cii of U-14C-L-Tyr and the other fowl which was supplied with the Phe-free diet for 36 day's and confirmed to maintain its positive nitrogen balance was injected $43.0, " \mathrm{Ci}$ of $2-14 \mathrm{C}-\mathrm{DL}-\mathrm{T} y \mathrm{r}$ at the left facies medialis intracelially.

They were killed by cutting the artery in the mouth. cavity $24 \mathrm{hr}$ after injection. Blood was collected in a beaker and mixed with equal volume of $200 \mathrm{o}(\mathrm{w}$ ) trichloroacetic acid (TCA). Immediately after the animal was killed, the liver and the pectoral muscle in the left side were taken out.

3. Preparation of protein sample. Blood samples, livers and muscles were soaked in $10^{\circ} \mathrm{TCA}$ T and minced and homogenized in Waring blender, and left at room temperature for $24 \mathrm{hr}$. These samples were treated as shown in Fig. 1 to get protein samples.

4. Isolation of Phe and Tyr. The method of isolation of Phe and Tyr was shown in Fig. 1.

Protein samples were hydrolyzed, filtered, concentrated and dissolved in $100 \mathrm{ml}$ of water. This solution $(50 \mathrm{ml})$ was concentrated to about $1 \mathrm{ml}$ in a rotary evaporator and drained into the active charcoal in $1.2 \times 15 \mathrm{~cm}$ columns. The columns were washed with 4 successive $5 \mathrm{ml}$ of $5^{\circ} \mathrm{o}$ acetic acid solution and eluted with $100 \mathrm{ml}$ of $5 \%$ ethyl acetate solution. The eluate containing aromatic amino acids was evaporated to dryness and was stripped on Toyo filter paper No. $514(40 \times 40 \mathrm{~cm})$ and was separated by paper chromatography using $n$-butyl alcohol, acetic acid and water $(4: 1: 1)$.

Both the Phe and Tyr fraction were extracted with $0.02 \mathrm{~N} \mathrm{HCl}$ and concentrated to dryness. Each dried fraction was again drained into the active charcoal column and eluted. The dried eluate was stripped on a sheet of paper. The extracted Phe and Tyr were filled up to $10 \mathrm{ml}$, separately, and an aliquot of them was taken on a stainless dish to measure its radioactivity with the thin-window type gas flow counter (Aloca Model PC-loC) or low back counter (Aloca LBC-1).

5. Identification of Phe. Phe isolated from liver and blood protein of the fowl had a radioactivity enough to be detected by the low back counter. Three examinations as indicated below were performed to remove the effect owing to contamination of radioactive $\mathrm{Tyr}$.

a) To oxidize contaminated Tyr, 2 drops of $1 \%$ $\mathrm{KMnO}_{4}$ solution were added to the stainless dish. 


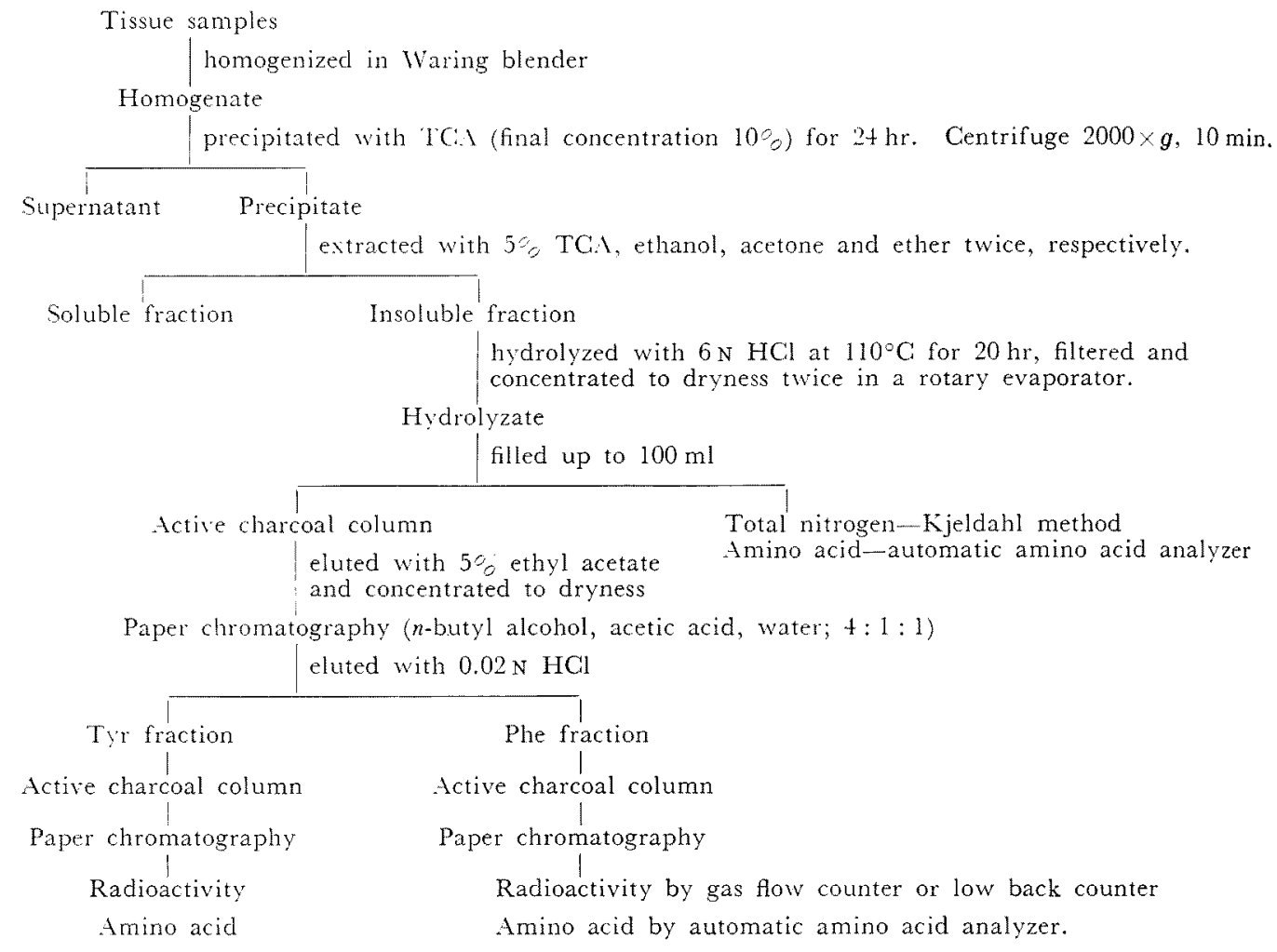

FIG. 1. Isolation of Phe and Tyr.

This dish was dried up on a water bath and its radioactivity was measured again.

b) An aliquot $(0.5 \mathrm{ml})$ of Phe fraction was again chromatographed with a paper. This paper was laid on S-ray film in the cassette for 3 months.

c) Dinitrophenylation was effected by stirring an aqueous solution of amino acid ( $20,1 \mathrm{M}$ in $3 \mathrm{ml})$ with a slight excess of 1-fluoro-2,4-dinitrobenzene (FDNB) for $80 \mathrm{~min}$ at $\mathrm{pH} 9.0$ and $40^{\circ} \mathrm{C}$. Excess FDNB was then extracted with ether, the solution was acidified, and the amino acids were extracted with ether $(5 \mathrm{ml} x$ 5). The aqueous solution containing dinitrophenyl amino acid was dried and separated by silicagel $G$ thin-layer chromatography using n-propanol, $34 \%$ ammonia (7:3). After elution by ether, its radioactivity was measured.

6. Position of ${ }^{14} \mathrm{C}$ in Phe. Following two examinations were performed to confirm the position of incorporated ${ }^{14} \mathrm{C}$ in Phe. a) $\mathrm{K}_{2} \mathrm{Cr}_{2} \mathrm{O}_{7}$ and $\mathrm{H}_{2} \mathrm{SO}_{4}$ were added to the Phe fraction to derive benzoic acid.
Benzoic acid formed was extracted with ether and its radioactivity was measured in the stainless dish.

Liberated $\mathrm{CO}_{2}$ was caught in $0.20 \mathrm{Ba}(\mathrm{OH})_{2}$ solution.

Radioactivity of $\mathrm{BaCO}_{3}$ was measured after washing with water.

7. Specific activities of other amino acids. Other amino acids of liver proteins were separated using the Hitachi amino acid analizer PL-II type and radioactivities of them were measured after removal of buffer salts by ion exchange column chromatography.

Quantitative amino acid analysis was performed on the automatic amino acid analyzer, which was developed in our labolatory of Nutritional Chemistry and Animal Nutrition in 1967.

\section{RESULTS}

Table I shows that the rats fed a Phe-free diet decreased food intake and could not 
Table I. Specific Activity of Phe and Tyr of Rat Liver Protein

\begin{tabular}{|c|c|c|c|}
\hline Rat no. & 1 & 2 & 3 \\
\hline Body weight (initial), g & 282 & 289 & 342 \\
\hline Body weight (final), $\mathrm{g}$ & 273 & 268 & 311 \\
\hline Food intake, $g$ day & 6.2 & 4.8 & 8.6 \\
\hline Liver, $\mathrm{g}$ & 8.8 & 9.0 & 13.0 \\
\hline Liver protein, $\mathrm{g}$ & 1.11 & 1.26 & 1.57 \\
\hline Phe/Tyr in liver protein & 1.31 & 1.37 & 1.27 \\
\hline $\begin{array}{l}\text { Specific activities } \\
\quad \text { of } T y r, c p m / \mu m o l e\end{array}$ & 190 & 154 & 177 \\
\hline $\begin{array}{l}\text { Specific activities } \\
\text { of Phe, cpm ":mole }\end{array}$ & 0.3 & 0.2 & 0.5 \\
\hline $\begin{array}{l}\text { Total }{ }^{14} \mathrm{C}-\mathrm{Phe} / \\
\text { Total }{ }^{14} \mathrm{C}-\mathrm{T} y \mathrm{r},{ }^{\circ}\end{array}$ & 0.21 & 0.18 & 0.36 \\
\hline
\end{tabular}

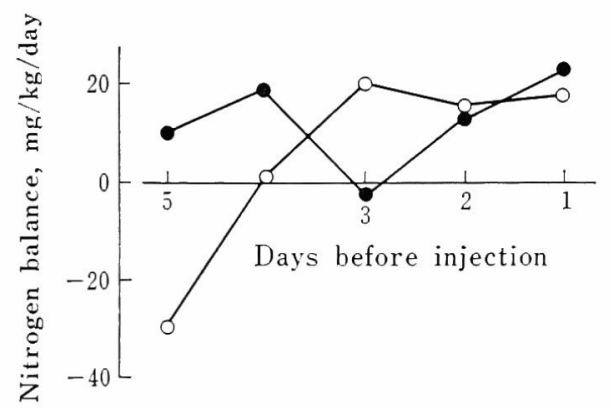

FIG. 2. Nitrogen Balance before Injection of U-14CL-Tyr $(O-O)$ and $2-{ }^{14} \mathrm{C}-\mathrm{DL}-\mathrm{T}$ yr

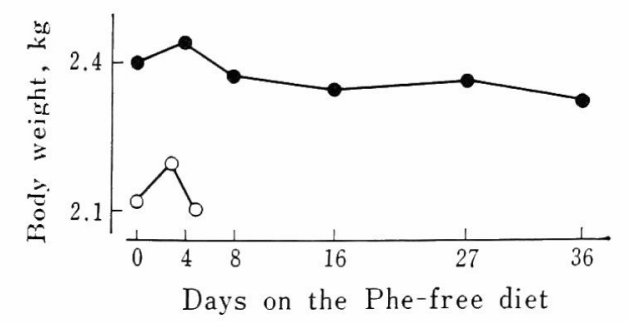

FIG. 3. Body Weight Changes of the Fowls Fed the Phe-free Diet.

$$
\underset{\text { injected }}{\mathrm{O}-\mathrm{O}-14 \mathrm{C}-\mathrm{L}-\mathrm{Tyr} \text { and }}
$$

maintain body weight but the fowls fed the Phe-free diet maintained their positive nitrogen balances for at least 4 days before isotope injection as shown in Fig. 2. The body weight was maintained almost constant during a period when the Phe-free diet was supplied (Fig. 3).

After injection of ${ }^{14} \mathrm{C}-\mathrm{T} y \mathrm{r}$, Phe and Tyr in hydrolyzates of liver and blood proteins of the fowls were separated on paper chromatogram which gave visible spots on the X-ray film.

Phe isolated by active charcoal column and paper chromatography also gave a visible spot

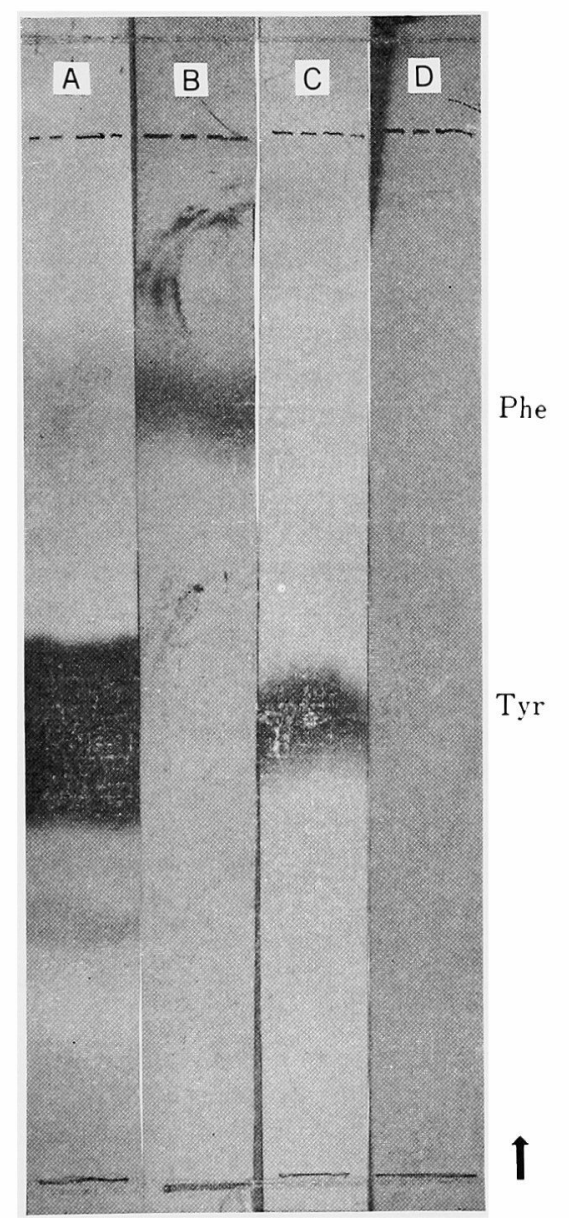

FIG. 4. X-ray Film of Paper Chromatogram.

A, hydrolyzate of the fowl liver protein.

$B$, isolated Phe from the fowl liver protein.

$\mathrm{C}$, hydrolyzate of the rat liver protein.

$\mathrm{D}$, isolated Phe from the rat liver protein. 
on the I-ray film. But Phe in hydrolyzates of rat liver proteins gave no visible spot on the X-ray film as shown in Fig. 4.

Since ${ }^{14} \mathrm{C}$-Tyr added to Phe (Ajinomoto Co., Inc.) was completely removed from Phe by twice repeated paper chromatography, the spot of Phe derived from liver proteins of fowls (Fig. 4B) was confirmed to be due to radioactivity of isolated Phe itself.

Specific activities of isolated Phe and Tyr in the rat liver proteins are summarized in Table I. Specific activity of Phe of 3 rats averaged to be $0.3 \mathrm{cpm} /$ umole and that of Tyr $174 \mathrm{cpm} / \mu$ mole. Ratio of total ${ }^{14} \mathrm{C}$-Phe to total ${ }^{14} \mathrm{G}$-Tyr in the liver protein was calculated to be $0.25 \%$ in average. Specific activities of Phe and Tyr in liver, blood and muscle of the fowls injected $\mathrm{U}-{ }^{14} \mathrm{C}-\mathrm{L}-\mathrm{Ty}$ r or $2-{ }^{14} \mathrm{C}$-DL-Tyr are summarized in Table II.

When $\mathrm{U}-{ }^{14} \mathrm{C}-\mathrm{L}-\mathrm{Tyr}$ was injected, specific activities of Phe in liver, blood and muscle were $4.6,3.9$ and $0.9 \mathrm{cpm} / \mu$ mole, respectively,

Table II. Specific Activities of Phe and Tyr in Tissue Proteins of the Fowls SACRIficed 24 HR AFTER INJECTION

\begin{tabular}{|c|c|c|c|}
\hline Tissue & Liver & Blood & Muscle \\
\hline Injected isotope & \multicolumn{3}{|c|}{$\mathrm{L}-1+\mathrm{C}_{-}^{\prime}-\mathrm{L}-\mathrm{T} y \mathrm{r}$} \\
\hline Tissue weight, $\mathrm{g}$ & 36 & 82 & 72 \\
\hline Tissue protein, $\mathrm{g}$ & 7.2 & 5.4 & 15.1 \\
\hline Phe Tyr & 1.43 & 2.94 & 1.53 \\
\hline $\begin{array}{l}\text { Specific activity } \\
\text { of } T_{y} \mathrm{r}, \mathrm{cpm} / \mu \text { mole }\end{array}$ & 893 & 755 & 89.3 \\
\hline $\begin{array}{l}\text { Specific activity } \\
\text { of Phe, cpm/umole }\end{array}$ & 4.6 & 3.9 & 0.9 \\
\hline $\begin{array}{l}\text { Total }{ }^{14} \text { C-Phe } \\
\text { Total }{ }^{14 C-T y r},\end{array}$ & 0.74 & 1.55 & 1.46 \\
\hline Injected isotope & \multicolumn{3}{|c|}{$2.14 \mathrm{C}-\mathrm{DL}-\mathrm{T}$ yr } \\
\hline Tissue weight, $\mathrm{g}$ & \pm 2 & 76 & 70 \\
\hline Tissue protein, $\mathrm{g}$ & 7.8 & 5.6 & 14.8 \\
\hline Phe Tyr & 1.29 & 2.89 & 1.73 \\
\hline $\begin{array}{l}\text { Specific activity } \\
\text { of Tyr, cpm/umole }\end{array}$ & 618 & 452 & 61.6 \\
\hline $\begin{array}{l}\text { Specific activity } \\
\text { of Phe, cpm///mole }\end{array}$ & 3.5 & 3.0 & 0.4 \\
\hline $\begin{array}{l}\text { Total }{ }^{14} \mathrm{C}-\mathrm{Phe} \\
\text { Total }{ }^{14 \mathrm{C}-\mathrm{Tyr}},{ }^{\circ}\end{array}$ & 0.73 & 1.92 & 1.12 \\
\hline
\end{tabular}

TABle III. Specific Activities of Phe, Tyr and Other Amino Acids of the Liver Proteins OF THE FOWLS INJECTED U-14C-L-TYR AND 2-14C-DL-TYR (cpm//umole)

\begin{tabular}{lcc} 
Amino acid & U-14C-Tyr & 2-14C-Tyr \\
\hline Asp & 0.2 & 0.1 \\
Thr+Ser ${ }^{a}$ ) & 0.2 & 0.0 \\
Pro & 0.2 & 0.2 \\
Glu & 0.2 & 0.1 \\
Gly & 0.1 & 0.1 \\
Ala & 0.2 & 0.1 \\
Val & 0.0 & 0.0 \\
Met & 0.0 & 0.1 \\
Ileu & 0.0 & 0.0 \\
Leu & 0.0 & 0.0 \\
Tyr & 839 & 618 \\
Phe & 4.6 & 3.5 \\
His & - & 0.0 \\
Lys & 0.0 & 0.1 \\
Arg & 0.0 & 0.2 \\
\hline
\end{tabular}

a) calculated as mixture.

and those of Tyr were 893,755 , and 89.3 cpm/ $\mu$ mole.

When $2-{ }^{14} \mathrm{C}$-DL-Tyr was injected to the fowl, specific activities of Phe in liver, blood and muscle were $3.5,3.0$ and $0.4 \mathrm{cpm} / \mu$ mole and those of Tyr were 618,452 and $61.6 \mathrm{cpm} /$ $\mu$ mole, respectively.

Ratios of total ${ }^{14} \mathrm{C}-\mathrm{Phe}$ to total ${ }^{14} \mathrm{C}-\mathrm{Tyr}$ in liver, blood and muscle protein when $\mathrm{U}-{ }^{14} \mathrm{C}$ Tyr was injected, were calculated to be 0.74 , 1.55 and $1.46 \%$ and those when $2{ }^{14} \mathrm{C}-\mathrm{Tyr}$ was injected were calculated to be $0.73,1.92$ and $1.12 \%$.

Specific activities of other amino acids were all lower than $0.2 \mathrm{cpm} / \mu$ mole as shown in Table III.

Radioactivity of $\mathrm{Phe}$ isolated from liver proteins of the fowls injected U- or $2-{ }^{14} \mathrm{C}-\mathrm{Tyr}$ was enough to be detected by the low back counter. It was confirmed by the following observations that radioactivity of isolated Phe was not due to that of contaminated Tyr, but to that of Phe itself.

a) The values of radioactivity of isolated 
Phe in the stainless dish $(37 \mathrm{cpm} / \mathrm{dish})$ did not change $(37 \mathrm{cpm})$ after 2 drops of $10^{\circ} \mathrm{KMnO}_{4}$ solution were added.

b) DNP-Phe had radioactivity which was completely free from contamination of Tyr.

c) The purity of isolated Phe was confirmed by paper chromatography, infrared spectrometer and automatic amino acid analyzer.

In the paper chromatogram, no ninhydrin positive substance except Phe was found and contamination of Tyr was less than $0.1 \%$, if any, because infrared spectrometer can point out 0.1 .8 Tyr added to Phe.

Automatic amino acid analyzer can find out the presence of $\mathrm{Tyr}$ at least at $0.0001 \mu$ mole, but no peak of Tyr was found in the chart, even in loading $10 \mu$ mole of Phe. So, the contamination of Tyr in Phe fraction could be calculated to be less than $0.0010^{\circ}$. Even if radioactivity of Phe fraction was due to contamination of Tyr in the case of liver, $0.001, u$ mole of Tyr at most would be contained in 1 , mole Phe and have $0.893 \mathrm{cpm}$ of radioactivity. This value is less than that of Phe $(4.6 \mathrm{cpm})$. So it might be concluded that ${ }^{14} \mathrm{C}$ of isolated Phe had derived from the carbon skeleton of injected $\mathrm{U}-{ }^{14} \mathrm{C}-\mathrm{L}-\mathrm{T}$ yr.

As it was clear that isolated Phe from liver protein had nothing but its own radioactivity, the position labeled by ${ }^{14} \mathrm{C}$ in $\mathrm{Phe}$ was determined, as shown in Table IV.

a) $1.6 \%$ of radioactivity of Phe was recovered in $\mathrm{CO}_{2}$ when ninhydrin was added to Phe of liver protein of the fowl injected $\mathrm{U}-{ }^{14} \mathrm{C}-\mathrm{T}$ yr but no radioactivity was found in $\mathrm{CO}_{2}$ when $2-{ }^{14} \mathrm{C}-\mathrm{Tyr}$ was injected.

b) Radioactivity of Phe fraction in the dish was not changed after addition of ninhydrin, when $2-{ }^{14} \mathrm{C}-$ Tyr was injected.

These results suggest that ${ }^{14} \mathrm{C}$ was not localized in carbon atom $1(\mathrm{COOH})$ of Phe when $2-{ }^{14} \mathrm{C}$-Phe was injected, but some localized in carbon atom 1 when $\mathrm{U}-{ }^{14} \mathrm{C}-\mathrm{Tyr}$ was injected.

c) $3.0 \%$ of radioactivity of Phe was recovered in liberated $\mathrm{CO}$ and $32.7 \%$ from benzoic acid when $\mathrm{K}_{2} \mathrm{Cr}_{2} \mathrm{O}_{7}+\mathrm{H}_{2} \mathrm{SO}_{4}$ were added to Phe of liver protein of the fowl injected $\mathrm{U}^{14} \mathrm{C}-\mathrm{Tyr}$, but when $2-{ }^{14} \mathrm{C}-\mathrm{Tyr}$ was injected, $42.20^{\circ}$ of radioactivity was recovered in liberated $\mathrm{CO}_{2}$ but only $0.2 \%$ from derived benzoic acid. These results indicated that ${ }^{\text {" }} \mathrm{C}$ was localized in carbon atom 3 to 9 of Phe when $\mathrm{U}^{14}-\mathrm{C}-\mathrm{Tyr}$ was injected, and ${ }^{14} \mathrm{C}$ only in carbon atom 2 and never in 3 to 9 of Phe when $2{ }^{14} \mathrm{C}$-Tyr was injected.

The yield of benzoic acid in this reaction was less than $50 \%$ of theoretical value. Benzoic acid obtained was identified by infrared spectrometer.

\section{DISCUSSION}

The fowls fed the Phe-free diet maintained their positive nitrogen balances and the rats decreased food intake and lost their body

Table IV. Position Labeled By $14 \mathrm{C}$ in Phe Isolated from Liver Protein of THE FOWL

\begin{tabular}{|c|c|c|c|}
\hline Treatment & Injected isotope & Recovered radioactivity & $\theta_{0}$ \\
\hline 0.35 Ninhydrin & $\mathrm{U}-14 \mathrm{C}-\mathrm{T} y \mathrm{r}$ & $\begin{array}{l}\text { Liberated } \mathrm{CO}_{2} \\
\text { Residual compounds }\end{array}$ & $\begin{array}{r}1.6 \\
99.0\end{array}$ \\
\hline $0.3 \%$ Ninhydrin & $2.24 \mathrm{C}-\mathrm{Tyy}$ & $\begin{array}{l}\text { Liberated } \mathrm{CO}_{2} \\
\text { Residual compounds }\end{array}$ & $\begin{array}{r}0.0 \\
100.0\end{array}$ \\
\hline $\mathrm{K}_{2} \mathrm{Cr}_{2} \mathrm{O}_{7}+\mathrm{H}_{2} \mathrm{SO}_{4}$ & $\mathrm{~L}-14 \mathrm{C}-\mathrm{Tyr}$ & $\begin{array}{l}\text { Liberated } \mathrm{CO}_{2} \\
\text { Derived benzoic acid }\end{array}$ & $\begin{array}{r}3.0 \\
32.7\end{array}$ \\
\hline $\mathrm{K}_{2} \mathrm{Cr}_{2} \mathrm{O}_{7}+\mathrm{H}_{2} \mathrm{SO}_{4}$ & $2-1 * \mathrm{C}-\mathrm{Tyr}$ & $\begin{array}{l}\text { Liberated } \mathrm{CO}_{2} \\
\text { Derived benzoic acid }\end{array}$ & $\begin{array}{r}+2.2 \\
0.2\end{array}$ \\
\hline
\end{tabular}


weights for 4 days.

If the transmission of ${ }^{14} \mathrm{C}$ of $\mathrm{Tyr}$ to ${ }^{14} \mathrm{G}$ of Phe occurs in vivo, in contrast with the results of Udenfriend $e t$ al. ${ }^{15)}$ and Funabiki et al., ${ }^{171}$ ${ }^{14} \mathrm{C}$ labeled Phe must be present in the tissue protein.

The subject of this paper was to confirm quantitatively the possibility of conversion of Tyr to Phe, and only protein fractions were dealt.

The isolated Phe from liver, blood and muscle protein of the fowls and those from liver proteins of rats had definite but low radioactivity.

In the case of the fowls, the transmission of ${ }^{14} \mathrm{C}$ from $\mathrm{Tyr}$ to Phe was not due to contamination of radioactive $\mathrm{Tyr}$, because a) radioactivity of Phe were observed after $\mathrm{Tyr}$ was destroyed by $\mathrm{KMnO}_{4}$, b) DNP-Phe had also radioactivity and c) radioactivity of contaminated Tyr was, if any, less than that of Phe according to the calculation from the purity of Phe confirmed by automatic amino acid analyzer.

And this transmission of ${ }^{14} \mathrm{C}$ from $\mathrm{Tyr}$ to Phe might not be due to transcarboxylation because a) ${ }^{14} \mathrm{C}$ was not found in $1-\mathrm{C}$ of Phe of liver protein when $2-{ }^{14} \mathrm{C}$-Tyr was injected and b) ${ }^{14} \mathrm{C}$ was found in 3 to $9-\mathrm{C}$ of the when $\mathrm{U}-{ }^{1+} \mathrm{C}$-Tyr was injected.

It was also suggested that this transmission of ${ }^{14} \mathrm{C}$ from $\mathrm{Tyr}$ to Phe was selective, because a) no spot except those of Phe and Tyr was observed on the X-ray film of the paper chromatogram of liver protein hydrolyzate and b) only negligible radioactivities were observed in all amino acids except the two amino acids.

Although specific activity of Phe isolated from rat liver protein was too low to be detected by low back counter, it would be insufficient to deny the possibility of transmission of ${ }^{14} \mathrm{C}$ from $\mathrm{Tyr}$ to $\mathrm{Phe}$ in rats.

In fact, this extent of specific activity of Phe was observed by Funabiki et al. ${ }^{17}$ They concluded that the conversion rate of Tyr to
Phe was too little to meet the Phe requirement.

As the dietary intake of Tyr was $20 \mathrm{mg} / \mathrm{kg}$ body weight/day, $0.14 \mathrm{mg}$ Tyr (20 $\mathrm{mg} \times 0.7 \%$ total ${ }^{14} \mathrm{C}$-Phe/total ${ }^{14} \mathrm{C}$-Tyr in the carcass including liver, blood and muscle) was calculated to be converted to Phe in the fowl. On the other hand, nitrogen intake was $265 \mathrm{mg} / \mathrm{kg}$ body weight/day and amount of Phe in the body protein equivalent to $265 \mathrm{mg} \mathrm{N}$ was calculated to be $69.6 \mathrm{mg}$ (265 $\mathrm{mg} \mathrm{N} \times 4.2 \mathrm{~g}$ Phe $/ 16 \mathrm{~g} \mathrm{~N}$ whole body protein).

The ratio of Phe converted from Tyr to that in the protein equivalent to $265 \mathrm{mg} \mathrm{N}$ was calculated to be $0.20^{\circ}(0.14 \mathrm{mg} / 69.6 \mathrm{mg} \times 100)$. This calculated amount of Phe would be too little to permit the possibility that a fowl maintains its positive nitrogen balance by supply of Phe converted from Tyr.

These results would support the conclusion that conversion of $\mathrm{Tyr}$ to Phe was definite and its rate was too little to compensate the deficient Phe on the Phe-free diet by conversion of Tyr to Phe in the adult rooster.

It is the further subject of studies whether the transmission of ${ }^{14} \mathrm{C}$ of $\mathrm{Tyr}$ to Phe may be promoted by enzymatic levels or microbes in the intestine or not.

\section{REFERENCES}

1) R. E. Smith and II. M. Scott, J. Nutr., 86, 37 (1965).

2) idem, ibid., 86, 45 (1965).

3) W. L. Stockland, I'. E. Lai, R. J. Meade, J. E. Sowers and G. Oestemer, ibid., 101, 177 (1971).

4) W. C. Rose and M. Womack, J. Biol. Chem., 166, $103(1946)$.

5) P. B. Rama Rao, H. W. Norton and B. C. Johnson, J. Nutr., 73, 38 (1961).

6) H. H. Williams, V. Curtin, J. Abraham, J. K. Loosli and L. A. Maynard, J. Biol. Chem., 208, 277 (1954).

7) M. P. Armstrong, ibid., 213, 409 (1955).

8) G. A. Leveille, R. Shapiro and H. Fisher, $J$. Nutr., 72, 8 (1961).

9) D. Johnson and H. Fisher, ibid., 60, 275 (1960).

10) T. Ishibashi, under contribution to Agr. Biol. Chem. 
11) idem, under contribution to Jap. J. Zontech. Sci.

12) idem, under contribution to Jap. J. Zootech. Sci.

13) S. G. Aquist, teta Chemica Scandinavica, 5, 1046 (1951).

14) S. Ldenfriend and J. Cooper, J. Biol. Chem., 194 , 503 (1952).
15) S. Udenfriend and C. Mitoma, A Symposium on Amino Acid Metabolism, 876 (1955).

16) C. R. Grau and R. Steele, J. Nutr, 50, 59 (1954).

17) R. Funabiki and M. Kandatsu, Nippon Nogeikagaku Kaishi, 39, 307 (1965). 